\title{
JOHN LOCKE E O LIBERALISMO POLÍTICO: UMA ANÁLISE DO DIREITO DE PROPRIEDADE E DA SEPARAÇÃO DE PODERES EM "DOIS TRATADOS DO GOVERNO CIVIL"
}

\author{
Maurício Pires Guedes* \\ Hector Luiz Martins Figueira ${ }^{* *}$
}

\section{RESUMO}

As ideias de propriedade e de separação de poderes surgem com os ideais liberais que remontam o final do século XVII. Tais questões são normalmente atrelados a obra de John Locke, cuja importância é inegável para o desenvolvimento do pensamento político ocidental. O objeto que se pretende tratar no presente artigo, a função da propriedade e a separação das funções estatais, a partir dos debates realizados pelo referido autor, refletem bem esta condição. Serão estes traços que se pretenderá apontar, buscando-se, na historicidade, o reconhecimento fundamental da própria experiência do direito e do Estado.

Palavras-chave: John Locke; Liberalismo político; Propriedade; Separação de poderes; Governo Civil.

\section{JOHN LOCKE AND POLITICAL LIBERALISM: AN ANALYSIS OF PROPERTY RIGHT AND THE SEPARATION OF POWERS IN "TWO TREATISES OF GOVERNMENT"}

\begin{abstract}
The ideas of property right and separation of powers arise with liberal ideals dating back to the end of the seventeenth century. Such questions are usually linked to the work of John Locke whose importance is undeniable for the development of Western political thought. The object to be treated in this article, the function of property right and the separation of state functions, from the debates carried out by this author, reflect well this condition. These traits are intended to be pointed out, seeking in the historicity the fundamental recognition of the experience of law and the State itself.
\end{abstract}

Keywords: John Locke; Political liberalism; Property; Separation of powers; Government.

\section{Introdução:}

O conceito de Estado deve ser compreendido a partir de uma perspectiva histórica, cujas bases foram sendo paulatinamente construídas em razão das distintas relações estabelecidas entre o poder social e as pessoas que a ele se subordinavam. Sob o ponto de

\footnotetext{
* Mestre em Direito pela Universidade Gama Filho e Doutorando em Direito pela Universidade Veiga de Almeida. Professor Universitário e Advogado. Endereço postal: Rua Raul de Leoni, no 14, sala 212, centro, Petrópolis-RJ. Endereço eletrônico mauriciopguedes@ gmail.com

** Mestre em Direito pela Universidade Veiga de Almeida e Doutorando em Direito pela Universidade Veiga de Almeida. Professor Universitário e Advogado. Endereço postal: Avenida Oswaldo Cruz, n ${ }^{\circ}$ 90, apt $^{\circ} 710$, Flamengo, Rio de Janeiro -RJ. Endereço eletrônico: hectorlmf@ hotmail.com
} 
vista moderno, o estudo da Estado deve ser realizado tendo como referência a sua historicidade, fruto das distintas concepções de soberania e de liberdade ao longo dos últimos séculos.

A noção de soberania como suprema potestas superiorem non recongnoscens, ou seja, poder supremo que não reconhece outro acima de si, de acordo com Ferrajoli (2002), remonta o surgimento dos Estados Nacionais Europeus por influência do Império Romano, tendo recebido, desde o final da Idade Média até o final do século XIX, múltiplos enfoques que alimentaram a delimitação de seu conteúdo.

A ideia de liberdade individual, em outro sentido, surge a partir dos ideais liberais que remontam o final do século XVII mas que somente vem a florescer com as revoluções iluministas do século seguinte, pressupondo, em certa medida, a limitação do Poder Político soberano tendo como referência a demanda por liberdades públicas dos indivíduos face ao Estado.

Esta limitação ao poder soberano, verdadeira mola-mestre para o surgimento do Estado contemporâneo, foi permeada pelo desenvolvimento de diversos elementos estatais que marcam as sociedades políticas ainda hoje, como por exemplo a ideia de constitucionalismo, de propriedade, de separação das funções estatais e de liberdades públicas em geral.

Duas destas ideias, o direito de propriedade e a separação de poderes, consideradas alicerces para o surgimento e a consolidação do Estado liberal burguês, são normalmente atrelados à obra "Dois tratados do governo civil" de John Locke, filósofo político inglês cuja importância, de fato, é inegável para o desenvolvimento do pensamento político ocidental.

Com efeito, a adequada compreensão das lições de Locke, no entanto, especialmente na segunda parte da obra supracitada, nos indica que o conceito e a abrangência da ideia de propriedade e de separação de poderes não se adequam, ao menos da forma como comumente se afirma no mundo jurídico em geral, àquilo que de fato foi incorporado posteriormente pelo Estado contemporâneo, o que não nos impede de concluir que a crítica realizada a partir de suas ideias permitiram as alterações conjecturais realizadas posteriormente pelos autores que o sucederam.

O objeto que se pretende tratar no presente artigo, a função da propriedade, por um lado, e a separação das funções estatais, por outro, a partir dos debates realizados por John Locke nos "Dois tratados do governo civil", demonstram a importância deste autor para o surgimento e a modelação do Estado moderno, refletindo bem esta condição. 
A introdução da referida obra publicado pela editora Almedina qualifica Locke como sendo "uma das figuras maiores da civilização ocidental moderna", "pensador da subjectividade", "dos direitos naturais", filósofo da epistemologia, da política, da religião, da educação; o economista, o constitucionalista, o exegeta, o assessor político, o professor universitário" (LOCKE, 2012,p.vii), o que, para além do propósito específico em si, demonstra, de certo modo, a riqueza do material por ele produzido e que foi pensado, repensado, criticado e aperfeiçoado ao longo dos últimos séculos.

Embora a distinção que se pretende realizar, no presente caso, apresente relativo alcance, já que os rumos da história demonstram a infiltração e contaminação entre acepções posteriores de distintos autores, certo é que certos modelos estatais apresentam relevantes traços próprios e característicos das ideias de John Locke que auxiliam, em nossa visão, o estudioso preocupado em compreender as bases políticas do mundo contemporâneo.

Nestes termos, iniciaremos nossa análise pela forma como John Locke apresenta o direito de propriedade e sua abrangência, onde será possível verificar que, diferentemente dos autores que lhe antecedem, a propriedade é concebida a partir de seu caráter natural - todos têm direitos as coisas -, o que o leva o referido autor a confundi-lo com a própria ideia de direito natural.

Em seguida buscaremos discutir a divisão do governo civil defendida por John Locke que, de certa maneira, vai de encontra as teses absolutistas defendidas tanto por Robert Filmer, a partir da soberania divina dos reis, como também de Thomas Hobbes, cuja referência para o exercício o poder já se fundava no contrato social.

Deve ser destacada a preocupação em Locke de estabelecer a limitação ao exercício do poder pela separação das funções do governo em três poderes distintos, dois na ordem interna e um na ordem internacional

O poder legislativo, que teria a tarefa de definir o modo pela qual seria definida a força da comunidade e suas normas para a preservação dela própria e de seus membros. $\mathrm{O}$ poder executivo, que teria o encargo de assegurar internamente a execução das leis positivas. E, por fim, o poder federativo, cuja atribuição passaria notadamente pela gestão das relações exteriores com outras sociedades politicamente organizadas.

Serão estes traços que se pretenderá apontar no presente artigo, buscando-se, na historicidade, o reconhecimento fundamental da própria experiência do direito e do Estado, o que, de certa forma, já aproxima este estudo da realidade contemporânea dentro do pensamento jurídico e político ocidental. 


\section{John Locke e o direito de propriedade:}

De fato, para a adequada compreensão deste tema, convém destacar que em 1632, quarenta e quatro anos depois de Thomas Hobbes, nasceu em Bristol, na Inglaterra, John Locke, no turbulento período de restauração dos Stuarts que somente se encerraria em 1660. Defensor do partido whig, e vencedor na revolução de 1688, Locke se colocou a serviço do partido com o objetivo de acalmar a inquietação e apaziguar as tensões de seus compatriotas.

Diante daqueles que viam a expulsão do Stuart Jaime II como violação ao sagrado soberano legítimo, poder este que se alicerçava na ideia da origem divina da soberania dos reis enquanto "representantes" de Deus na terra tal como afirmava Robert Filmer em seu famoso livro Patriarcha ${ }^{l}$, esta tese terá em Locke um dos seus principais contendores, sendo manifesto este posicionamento quando o referido autor defende a existência de direitos naturais do indivíduo já no estado de natureza como forma de desmistificar e deslegitimar o Estado absoluto.

Imperioso relevar que a justificativa para a inserção do homem no novo contexto social decorria em Locke da necessidade de se evitar alguns inconvenientes que poderiam advir do estado da natureza, aproveitando o referido autor deste momento para fixar diversos mecanismos e institutos anti-absolutistas na tentativa de evitar uma eventual retomada do poder semelhante ao existente no regime anterior.

O direito de propriedade, dentro desse contexto, surge como direito preexistente à instituição da sociedade civil, estando ligada diretamente à cada indivíduo. Nota-se especificadamente nesse ponto a relação que existe entre a teoria da propriedade e o estado de natureza para o referido autor: como a propriedade precede à sociedade civil, ela já se fazia presente no próprio estado de natureza.

Em outro sentido, o fenômeno da propriedade para Locke se entrelaçará diretamente com a noção de trabalho e apropriação útil das coisas, na medida em que o homem possui o trabalho de seu corpo e a obra de suas mãos, logo, qualquer coisa que o home retire do estado de natureza e misture com o seu trabalho se transformará em sua propriedade.

De fato, na formulação de Locke, a propriedade é um direito natural e inalienável, servindo de fundamento para a criação do governo civil e para a atribuição de direitos

\footnotetext{
${ }^{1}$ Título completo: Patriarcha, or, The natural power of Kings
} 
políticos aos indivíduos. Esse valor do indivíduo em si responsável pelo incremento de sua propriedade foi bem demonstrado por Bobbio ao afirmar que Locke "sustenta que o fundamento da propriedade individual devia ser procurado no trabalho, empregado para apropriar-se de uma coisa ou para transformá-la, valorizando-a economicamente” (1997, p.192)

É perceptível a ideia de uma ordem coletiva no estado natural das coisas que pode ser usada pelos homens em benefício próprio ou de forma particularizada. $\mathrm{O}$ direito de propriedade, enquanto consequência de uma apropriação legítima, prescinde da manifestação dos demais indivíduos e encontra na suficiência de recursos para a apropriação alheia, por um lado, e na proibição de desperdício, por outro, as únicas limitações ao exercício deste direito. “A mesma lei natural que, por este meio, nos confere a propriedade", diz Locke, "nos confere limites"(2012, p.254).

Estes limites são encontrados dentro da teoria lockeana a partir da própria interpretação de trechos religiosos indicados no livro "Dois tratados do governo civil", cuja aplicação decorreria da própria vontade de Deus em nosso mundo. "Deus deu-nos abundamente todas as coisas", $1^{\text {a }}$ Carta a Timóteo 6:17, o que levou Locke a reconhecer que o uso e gozo das coisas está permeado pelo benefício que estas coisas trazem antes que se deteriorem.

Nesse sentido, a deterioração das coisas pelo homem constituiria violação ao direito natural de propriedade, na medida em que, para Locke, "Deus nada criou para o homem desperdiçar e destruir" (2012, p.254) constituindo verdadeiro limite para o exercício deste direito:

\footnotetext{
Mas até que ponto nos deu ele [Deus] as coisas? Para dela gozarmos, tanto quanto alguém pode fazer uso das coisas para qualquer benefício da vida antes que se deteriorem; eis o quanto alguém pode apropriar-se por meio do seu trabalho. Tudo o que esteja para além deste limite excede a sua parte e pertence aos outros. (LOCKE, 2012, p, 254)
}

A suficiência de recursos para apropriação alheia, em outro sentido, constitui corolário lógico deste primeiro limite. Considerando a abundância das provisões naturais dentro do mundo pensado por Locke, e o reduzido número de homens que delas se apropria, não haveria óbices para o entendimento de que existem terras e bens suficientes para todos, o “dobro da população atual” segundo Locke (p. 258), certo de que a apropriação em excesso, diante desse quadro, constituiria ato desonesto a ser repudiado pelo pacto. 


\begin{abstract}
Assim, no princípio, o trabalho conferiu o direito de propriedade sempre que alguém se dispôs a empregá-lo em bens que eram comuns. Este tipo de bens foi ainda durante muito tempo de longe o mais numeroso, e ainda hoje a sua quantidade é superior à que o gênero humano pode utilizar. No início, os homens, na sua maioria, contentavam-se com o que a natureza em bruto lhes oferecia para satisfazer a sua necessidade. É verdade que posteriormente em algumas regiões do mundo, onde o aumento do número de pessoas e dos recursos, propiciado pelo uso do dinheiro, tornou a terra escassa e lhe deu algum valor, as várias comunidades estabeleceram fronteiras dos seus respectivos territórios e, mediante leis feitas entre si, regularam a propriedade de cada um dos particulares da sua sociedade. (LOCKE, 2012, p, 264)
\end{abstract}

A racional apropriação das coisas, portanto, constitui elemento norteador daquilo que é comum ou não a sociedade, de modo que sempre que o homem "retira seja o que for do estado em que a natureza o colocou, e aí o deixou, misturou o seu trabalho com esse objeto, e acrescentou-lhe algo que lhe é próprio, e assim converte-o em propriedade sua" (LOCKE, 2012, p, 251), conforme já mencionado acima. Ao subtrair o objeto do estado comum que a natureza o colocou, o trabalho exclui o direito comum dos outros homens sobre a coisa, o que, para Locke, justificaria a essência do direito de propriedade.

Convém desde logo esclarecer que a propriedade nos "Dois tratados do governo civil" poder ser encarada sob duas acepções: primeiramente em um sentido amplo, ou seja, segundo o qual ela designa, de forma simultânea, tanto a vida, quanto a liberdade e os bens do ser humano contra as ameaças do poder arbitrário, forma majoritariamente utilizada pelo autor ao longo do texto. Sob esta perspectiva, a propriedade constituirá instrumento a ser regulamentado pelo governo civil respaldando a superação do estado de natureza pelo estado político.

Dentro deste contexto, e de acordo com Aranha Martins (2009, p.305) o direito propriedade englobaria "tudo o que pertence a cada indivíduo", sendo que "a primeira coisa que a pessoa possui, portanto, é o seu corpo: todo indivíduo é proprietário de si mesmo e de suas capacidades", ou seja, tudo sobre o qual o homem atuou para o seu próprio sustento e para a sua existência passa a ser dele.

O homem nasceria para Locke com todos os privilégios do estado de natureza, de modo que tudo aquilo que lhe fosse próprio, tal como sua vida, a sua liberdade e seus bens, constituiria objeto de proteção de sua propriedade contra a investida de outros homens ou contra a investida de outros grupos, permitindo inclusive a aplicação de pena as infrações à lei natural quando a ofensa assim justificasse.

Relevante notar, nesse ponto, que embora Locke reconheça que as coisas da natureza sejam dadas em comum ao homem, este, por ser senhor de si mesmo e proprietário da sua 
própria pessoa, exclui o direito comum de outros homens quando se apropria pelo trabalho, das coisas que deixam de pertencer a comunidade. Nesse sentido, esclarece Locke:

\begin{abstract}
Embora todos os frutos que a terra naturalmente produz, todos animais que alimenta, pertençam em comum à humanidade, por serem produzidos pela mão espontânea da natureza; e apesar de ninguém deter originariamente um domínio privado com exclusão dos outros de nenhum destes bens, por estes se encontrarem no seus estado natural; contudo, como foram dados para o uso do homem, tem necessariamente de haver algum meio de apropriá-los para que possam ser de alguma utilidade ou trazer algum benefício a um determinado homem. (LOCKE, 2012, p. 251)
\end{abstract}

É dentro deste ponto, tendo como referência propriedade em sentido amplo, é que Locke defenderá a imperiosa necessidade de superação do estado de natureza e a sua conversão no estado político, fruto das instabilidades políticas decorrentes da ausência de uma lei estabelecida, de um juiz imparcial e da coercitividade de suas decisões:

\begin{abstract}
Mas como nenhuma sociedade política pode existir, nem subsistir, sem possuir em si mesma o poder de proteger a propriedade e, tendo em vista esse fim de punir as ofensas de qualquer um dos seus membros; nesse caso, e só nesse caso, é que existe uma sociedade política, em que cada um dos seus membros renunciou a este poder natural e entregou-o nas mãos da comunidade para que fosse exercido todas as vezes em que as circunstâncias particulares não excluíssem o recurso à proteção da lei por ela estabelecida. (LOCKE, 2012, p. 289)
\end{abstract}

Esta acepção mais ampla do direito de propriedade vai aderir a ideia de apropriação, o que leva a ideia de propriedade em sentido estrito, ou seja, aquela que remete à posse de bens móveis ou imóveis em geral, tal como o sentido contemporâneo dado a este direito. Esta concepção se torna relevante a especialmente a partir do momento em que Locke insere a ideia de dinheiro neste contexto, atribuindo-lhe uma nova dimensão econômica a partir do consentimento tácito dada pelos homens nesse sentido.

Com o surgimento da moeda enquanto bem não perecível torna-se possível converter bens sobre os quais os homens exercem propriedade em objeto de valia simbólico, entendimento este que coloca em xeque o desperdício enquanto elemento limitador da propriedade e que, para Locke, constituiria justificativa para a desigualdade entre os homens:

Assim, no princípio, o mundo inteiro era a América, e mais ainda do que é agora, pois nessa altura nenhuma região conhecia algo parecido com o dinheiro. Encontrai algo como o mesmo uso e valor do dinheiro, vereis o mesmo homem imediatamente começar a aumentar as suas posses. Como o ouro e a prata, tendo pouca utilizada para a vida do homem em termos de alimento, vestuário e transporte, obtêm o seu valor apenas do consentimento dos homens, cuja medida é determinada sobretudo pelo trabalho, é evidente que os homens consentiram que a terra fosse repartida de maneira desproporcionada e desigual. (LOCKE, 2012, p. 267) 
De fato, "os homens tornaram possível esta repartição desigual das posses privadas fora das fronteiras da sociedade, e sem que fosse preciso um pacto; bastou que atribuíssem valor ao ouro e à prata, e que concordassem tacitamente no uso do dinheiro (Locke, 2002, p.267).

Em resumo, em sua obra seminal, Locke defende que a propriedade é um direito natural inalienável de homens livres e iguais existente já no estado de natureza, pois a propriedade representa o direito à vida, a liberdade e aos bens, mas a criação do dinheiro, enquanto objeto de valor simbólico e que poderia vir a ser entesourado sem causar lesão aos demais, se tornaria instrumento de desigualdade, trazendo um sentido mais restrito da ideia de propriedade, o que somente seria admissível em razão do consentimento dado pelos homens no uso monetário dado a ele.

\section{3- Da divisão bipartida das funções internas do poder em John Locke:}

Em outro sentido, mas ainda baseada na engenhosa retórica trazida pelo autor para justificar a existência do direito de propriedade ainda no estado de natureza, aliada a instabilidade política decorrente da ausência de regulamentação fora do estado político, surge em Locke a defesa da imperiosa separação das funções governamentais dentro do governo civil, decorrente do pacto dos cidadãos firmados nessa nova formação social inaugurada.

A sociedade política constitui para Locke, portanto, a primeira referência para além do estado de natureza, legitimando, a partir do governo, a regulamentação dos direitos que já existiriam anteriormente.

\footnotetext{
Por conseguinte, sempre que um certo número de homens se une em sociedade, cada um deles renunciando ao seu poder executivo da lei natural e cedendo-o à comunidade, então, e só então, se constitui uma sociedade política ou civil. Tal sucede sempre que um certo número de homens que vivem no estado de natureza se associam para formar um povo e um corpo político, submetido a um governo supremo, ou quando alguém se junta e se incorpora num governo já constituído. Por esse meio, ele autoriza a sociedade ou, o que é dizer o mesmo, o seu poder legislativo, a fazer leis por sua conta, de acordo com as exigências do bem público da sociedade, e a solicitar a sua assistência para a execução dessas leis (como se tratasse de decretos de sua própria autoria). (LOCKE, 2012, p. 267)
}

A divisão apresentada por Locke, portanto, demonstra sua preocupação em evitar o abuso do poder que o assenhoramento de tais funções nas mãos de uma só pessoa ou um só grupo poderia levar, embora, de fato, não reste dúvida ter o referido autor propugnado uma 
maior relevância na atuação da função legislativa que representaria, ao menos em um primeiro plano, os interesses da sociedade política como um todo.

De fato, partindo dos poderes do homem no estado da natureza, Locke nos apresenta duas funções internas fundamentais para garantir a adequada estabilidade que o contrato social demandava: a legislativa, que teria a tarefa de definir o modo pela qual seria definida a força da comunidade e suas normas para a preservação dela própria e de seus membros; e a executiva, que teria o encargo de assegurar internamente a execução das leis positivas.

A existência do governo civil e seu exercício legítimo constituem pressupostos fundamentais para a superação do estado de natureza de Locke, de modo que o adequado funcionamento da partição dos poderes, e o efetivo cumprimento dos seus respectivos deveres, embasam e garantem o regular desenvolvimento do governo dentro do estado político.

Importante desde já consignar que a ausência de expressa menção ao poder judiciário como órgão autônomo do governo civil não retira a importância da existência de uma magistratura tal como hoje nos a conhecemos, com função específica, conforme se observa do seguinte trecho dos "Dois tratados do governo civil":

Os que estão unidos num único corpo, e que dispõem de uma lei comum
estabelecida e de uma judicatura à qual apelar, com autoridade para decidir os
diferendos entres eles, vivem uns com os outros numa sociedade civil. Mas aqueles
que não dispõem de alguém a quem apelar, quero dizer, a quem apelar neste mundo,
estão ainda no estado de natureza, na medida em que cada um, na ausência de um
juiz comum, é o seu próprio juiz e executor. (...) Desta forma, a comunidade política
adquire o poder de determinar os castigos correspondentes às várias transgressões
cometidas pelos membros dessa sociedade que lhe parecem ser apropriadas (o que é
o poder de legislar), assim como tem o poder de punir qualquer injúria feita a um
dos seus membros por alguém que não pertence à mesma sociedade (o que é o poder
da paz e da guerra). Ambos os poderes são exercidos com o fim de preservar a
propriedade de todos os membros da sociedade, tanto quanto possível. (LOCKE,
2012, p.290)

Sob o ponto de vista normativo propriamente dito, a primeira lei positiva a ser criada para Locke deveria estabelecer o poder legislativo, cuja atuação encontrava-se absolutamente limitada aquilo que previamente já estaria contemplada pelo direito natural, constituindo, em razão de seu caráter contratual, fator intransponível para a criação ou alteração do mundo político.

De fato, em razão de sua supremacia formal face aos demais poderes, o poder legislativo constitui a própria expressão do direito natural se refletindo no governo, na medida em que, para Locke, "como se trata da fusão de poderes que os membros sociedade (...) que 
assume o poder de legislar, (...) não pode exceder o poder que essas pessoas tinham no estado de natureza antes de entrarem na sociedades e o transferirem para a comunidade."(2012, p.322).

Com efeito, conforme deixa claro Locke em diversas oportunidades, a celebração do pacto de consentimento pressupunha a instabilidade política e social decorrente da ausência de lei estabelecida e da falta de parâmetros das respectivas sanções no estado de natureza, questões no entanto que pressuporiam o reconhecimento da permanência e incidência dos efeitos da lei natural mesma após a celebração do pacto. Nesse sentido, esclarece Locke:

\begin{abstract}
O seu poder [legislativo], na sua extensão máxima, é limitado pelo bem público da sociedade. Trata-se de um poder que não tem outro fim senão a preservação, e portanto jamais tem o direito de destruir, escravizar ou empobrecer deliberadamente os seus súditos. As obrigações da lei natural não cessam na sociedade; acontece que em muitos casos são delimitadas de forma mais estrita e são complementadas com penas atribuídas pelas leis humanas para garantir o seu cumprimento. Desta forma, a lei natural permanece como a regra eterna de todos os homens, sem exceptuar os legisladores. As regras a que estes submetem as acções dos outros homens, à semelhança das suas próprias acções, tem de ser conformar à lei natural, isto é, à vontade de Deus, da qual essa lei é uma manifestação. (2012, p, 323)
\end{abstract}

Deve restar claro, portanto, que Locke não está atribuindo a função legislativa o poder arbitrário de criar normas jurídicas, mas a suprema tarefa de estabelecer regras que já se encontram presentes no próprio estado de natureza.

O poder executivo, em outro sentido, é descrito por Locke como responsável direto pelo direito de cada indivíduo de exercer a lei natural, na medida em que, para o referido autor, seria demasiadamente perigoso permitir que aqueles que tem o poder de fazer as leis pudessem executá-las em seu próprio benefício, o que eventualmente poderia desviá-los dos fins próprios da sociedade e do governo.

Interessante notar que enquanto era conveniente que o poder legislativo estivesse exercendo suas funções periodicamente - as convocação seriam de tempos em tempos, salvo situações excepcionais - e por uma assembleia, o poder executivo deveria permanecer em constante exercício na medida em que, para Locke, "nem sempre há a necessidade de se fazer novas leis, mas é sempre preciso executar as leis já estabelecidas” (2012, p.334)

Dento dessa perspectiva, embora teoricamente inferior e submisso, o poder executivo desempenhava, à luz de um critério de relevância social, função de igual repercussão ao do legislativo, ao menos sob o ponto de vista pragmático, o que possibilitaria, como consequência do exercício de ambos, o famoso direito de resistência e revolta por parte dos 
cidadãos, considerado por Locke direito natural e, por isso mesmo, inerente à natureza humana.

E mais: defendia Locke que ambos poderes recebiam dos governados o mesmo consentimento daquele suposto poder supremo e superior, de modo que tanto um, como outro, estavam submissos à soberania e à confiança do povo. Era o próprio povo, em última instância, quem tinha o poder de confiar a administração de suas vidas a quem lhe aprouvesse.

No escólio Jean Jacques Chevalier, fica evidente que esta divisão trazida por Locke tem por finalidade resguardar a soberania do povo, na medida em que constitui o próprio povo o efetivo irradiador da legitimidade que marca o estado político por ele defendido:

\begin{abstract}
(...) embora Locke evite elaborar aqui uma construção rigorosa, o povo conserva sempre uma soberania potencial, em reserva: é ele, e não o legislativo, o detentor do verdadeiro poder soberano. (...) Quem julgará, entre o legislativo e o executivo, se este último fez bom ou mau uso da prerrogativa? Quem julgará, entre o legislativo e o povo, se o primeiro conspira para escravizar o segundo? Quem julgará, quem sancionará a fidelidade dos depositários (trustees) do poder, a eles confiado para o bem público? O povo, a título de depositante, "deve julgar a tal respeito". (CHEVALIER, 1999, p.115)
\end{abstract}

Ao lado destes dois poderes Locke também previu a existência do poder federativo, cuja atribuição passaria notadamente pela gestão das relações exteriores com outras sociedades politicamente organizadas, especialmente àquelas vinculadas a decretação da guerra, a celebração da paz e o estabelecimento de acordos ou alianças no âmbito daquilo que hoje denominamos de direito internacional.

Este poder federativo, embora distinto em si do poder executivo, assume para si a responsabilidade similar ao se encarregar da segurança e do interesse público tendo em vistas às relações exteriores, pressupondo, em Locke, que cada comunidade inteira formaria um único corpo que, em estado de natureza, poderia vir a estabelecer relações com outras comunidades ou com pessoas alheias a ela:

Em todas as comunidades políticas, existe ainda um outro poder, ao qual se pode chamar de natural, na medida em que se trata do poder que corresponde ao poder que todo o homem tinha naturalmente antes de entrar na sociedade. Pois embora os membros de uma comunidade política continuem a ser pessoas distintas nas suas relações mútuas, e enquanto tais são governados pelas leis da sociedade, já nas suas relações com o resto do género humano, eles constituem um só corpo, o qual ainda está, em relação ao resto do gênero humano, como estavam anteriormente todos os seus membros, ou seja, no estado de natureza. Daí que todas as controvérsias que ocorram entre um membro da sociedade e outras pessoas que se encontram fora da mesma sejam geridas pelo público e que uma injúria sofrida por um membro desse corpo envolva o todo da comunidade na tarefa de obtenção da reparação. Deste ponto de vista, a comunidade inteira forma um único corpo que permanece no estado 
de natureza em relação a todos os outros Estados ou pessoas alheias à comunidade. (2012, p, 330)

Nesse sentido, aliás, o próprio fato da comunidade "converter-se num árbitro, que, por intermédio de regras estabelecidas, imparciais e uniformes para todas as partes (...) decide todas as controvérsias que podem ocorrer entre quaisquer membros dessa sociedade" (LOCKE, 2012, p.289) perpassa pelo funcionamento efetivo dos três poderes em três momentos distintos: quando da criação da norma, pelo poder legislativo; quando da administração da sociedade política, pelo poder legislativo; e pela resolução de conflitos de interesses internacionais, pelo poder federativo.

$\mathrm{Na}$ introdução aos "Dois tratados do Governo Civil" publicado pela editora Almedina, já mencionado acima, é possível verificar a preocupação em vincular a Locke a ideia de primado da lei tal como contemporaneamente este tema é pensado, sobretudo a partir do viés liberal no sentido de que a lei passa a exercer a função de instrumento para o adequado exercício do poder pelo governo:

O governo das leis é simultaneamente um meio e um fim em si mesmo. Por um lado,
obedecer à lei consentida e justa é sintoma de razoabilidade. Num contexto político,
a vida racional desenvolve-se no cumprimento das leis. Mas, por outro lado, o
governo das leis está ao serviço da realização dos fins que os homens prosseguem
quando se reúnem numa comunidade política. Um governo que vive fora da lei ou
acima da lei - como as teorias clássicas das soberanias asseveravam - tende a violar
os direitos individuais dos seus súbditos. Contudo, se o governo das leis tem
também esta dimensão instrumental, então so fins da comunidade política e do
governo condicionam a sua primazia. O primado da lei que caracteriza o chamado
"governo constitucional" é posto em causa pelas razões que justificam esse governo
do direito e das formas legais. É que a necessidade e a contingência das ameaças aos
fins da comunidade política exigem que o governo tenha a capacidade de lhes
responder quando das formas institucionais-legais são insuficientes ou desadequadas
ou demasiado morosas. (2012, p, LXXVII- LXXVIII)

Necessário nesse ponto destacar que embora esta divisão seja absolutamente relevante para o debate atual sobre a matéria, não é possível incluir Locke como efetivo expoente da tríplice separação de poderes tal como restou consolidado com a formação do Estado moderno, faltando-lhe, de fato, a partir da especificidade do poder federativo conforme visto acima, um maior desenvolvimento que somente seria alcançado por Montesquieu posteriormente conforme bem esclarece FARIAS NETO:

O denominado poder federativo ficaria encarregado de gerir as relações exteriores, com outras sociedades politicamente organizadas, abrangendo a deliberação sobre guerra, paz, alianças e tratados. Ao poder legislativo, ficaria subordinado o poder executivo, confiado ao monarca, além do poder federativo. O poder executivo e o poder federativo poderiam, inclusive, ser exercidos pelo mesmo governante. A 
abordagem de Locke preceituou a existência de uma clara separação do poder legislativo em relação aos poderes executivo e federativo. Ao concentrar o poder executivo e o poder federativo, contudo, Locke não delineou a tripartição completa do poder, que ficou mais bem desenvolvida por Montesquieu (1689-1755), posteriormente, no século XVIII. (2011, p, 253)

De fato, não há, dentro do quadro delineado por Locke, expressa referência a função judicial a ser exercida independentemente dos demais poderes tal como atualmente nós a conhecemos, o que não significa, evidentemente, que não houvesse responsáveis por determinar a aplicação do direito em casos concretos de forma adequada

Muito pelo contrário, as competências do poder legislativo se tornavam muito mais relevantes quando com as do executivo a elas se uniam, na medida em que, ínsito a finalidade do governo, encontrava-se a necessidade de preservação da paz nas relações sociais.

Não por outro motivo, ao tratar "Dos fins da Sociedade Política e do Governo", capítulo IX do "segundo tratado", Locke ressalta a necessidade de instituir no estado político um juiz conhecido e imparcial com autoridade para resolver as ações que violassem a lei estabelecida, não deixando dúvidas da importância para a sociedade política desta atuação:

\begin{abstract}
Assim, não obstante todos os privilégios do estado de natureza, o gênero humano, enquanto permanece nesse estado, encontra-se numa má situação, e rapidamente é conduzido à sociedade. É por isso que raramente nos deparamos com homens que permaneçam durante algum tempo no estado de natureza. As inconveniências a que estão expostos pelo exercício irregular e incerto do poder que cada homem tem de punir as transgressões dos outros levam-nos a procuração refúgio nas leis estabelecidas de um governo e a tentar salvaguardar a sua propriedade. É por essa razão que cada qual está tão disposto a renunciar ao seu poder individual de punição para que seja exercido apenas por quem for designado entre eles, e segundo as regras que a comunidade, ou quem for autorizado para esse propósito, estabeleça de comum acordo. Encontramos aqui o direito originário quer do poder legislativo, quer do poder executivo, assim como dos governos e das próprias sociedades. (2012, p. 317)
\end{abstract}

Dessa forma, e diante desse quadro, fica evidente que a divisão trazida por Locke das funções entre poder executivo, legislativo e federativo, pelas razões acima expostas, tinha por finalidade, em última instância, resguardar a soberania da sociedade política da concentração de poderes em uma única pessoa ou em único órgão, o que permitiria, em sua visão, um maior equilíbrio no desenvolvimento das relações políticas e sociais.

Interessante observar, neste ponto, que a maneira como Locke desenvolve essa ideia contrastará com aquela empregada por Montesquieu em sua obra, embora o desenvolvimento da função executiva de Locke em duas realidades distintas - poder executivo e poder 
judiciário - acaba exatamente por caracterizar a tripartição apresentada e defendida pelo autor francês.

Com efeito, pela leitura do "Espírito das leis" fica bastante evidente como preocupação de usurpação do poder apresentada por Locke ecoou significativamente em Montesquieu, tendo merecido deste uma teorização muito mais completa e elaborada.

A grande novidade trazida pelo autor francês diz respeito ao fato de que a separação de poderes trazida por Locke poderia não ser suficientemente adequada na medida em que o poder de administrar e de julgar, quando confiados em uma única pessoa, poderia constituir instrumento de opressão não passível de limitação pelo Poder Legislativo por si só, pressuposto que é fulcral para a compreensão daquilo que marca o pensamento político e jurídico do mundo ocidental contemporâneo. Nesse sentido, esclarece Montesquieu:

Quando, na mesma pessoa ou no mesmo corpo de magistratura, o poder legislativo está reunido ao poder executivo, não existe liberdade; porque se pode temer que o mesmo monarca ou o mesmo senado crie leis tirânicas para executá-las tiranicamente. Tampouco existe liberdade se o poder de julgar não for separado do poder legislativo e do executivo. Se estivesse unido ao poder legislativo, o poder sobre a vida e a liberdade dos cidadãos seria arbitrário, pois o juiz seria legislador. Se estivesse unido ao poder executivo, o juiz poderia ter a força de um opressor. Tudo estaria perdido se o mesmo homem, ou o mesmo corpo dos principais ou dos nobres, ou do povo exercesse os três poderes: o de fazer as leis, o de executar as resoluções públicas e o de julgar os crimes ou as querelas entre os particulares. (2005, p. 168).

A equivalência ou equipotência na teoria da separação dos poderes trazida por Montesquieu inova, portanto, ao propiciar a existência de instâncias independentes que assegurassem que não houvesse o abuso por parte de quaisquer deles contra os demais ou contra os cidadãos, de modo que o equilíbrio decorreria da permanente interação entre tais funções.

Fica bastante evidente, portanto, que se princípio da separação de poderes recebe na França os elementos necessários à consolidação do Estado moderno e a superação do Antigo Regime, o paradigma de John Locke foi primordial para tanto, justificando, de certa maneira, a relevância dada a ele no estudo desta matéria.

\section{Considerações finais:}

De tudo o que foi exposto o que se observa, de fato, é que embora John Locke seja considerado por muitos o pai do liberalismo moderno, os limites por ele fixados das 
questões analisadas no presente artigo, quais sejam, a ideia de propriedade e os movimentos políticos da organização dos poderes estatais da tradição jurídica ocidental, surgem no livro "Dois tratados do governo civil" a partir de paradigmas distintos daqueles concebidos nos dias de hoje, não obstante tenha ficado claro, em outro sentido, que tais ideias, ainda que embrionárias, foram fundamentais para a efetiva construção realizada por outros teóricos posteriormente.

De fato, conforme visto em um primeiro momento, o fenômeno da propriedade se entrelaça diretamente com a noção de trabalho e apropriação útil da coisa, tanto que este direito prescinde da manifestação dos demais indivíduos.

Tal concepção somente revela-se possível diante da suficiência de recursos para a apropriação alheia por um lado, e na proibição de desperdício, por outro, bases indispensáveis para a legítima apropriação da coisa pela homem, permeando as limitações para o exercício deste direito.

Em outro sentido, pretendeu o presente artigo discutir as matrizes fundamentais do princípio da separação dos poderes, tendo sido paradigmática a sua posição no sentido de que a concentração de todos os poderes em uma só pessoa ou um só grupo acarretaria na inequívoca usurpação por parte de seu titular.

Nestes termos, sugere o referido autor a necessidade da bipartição dos poderes internos do Estado em legislativo e executivo, a fim de que possam se limitar mutuamente, certo de que a função judiciária, nesse espectro, constituiria mera consequência das tarefas do governo civil, cuja relevância, no entanto, pode ser observada em diversas passagens de sua obra conforme visto acima.

É necessário nesse ponto relembrar que o primado da lei constitui a base essencial para o adequado funcionamento do governo político, certo de que a divisão das suas funções entre poder executivo, legislativo e federativo, pelas razões acima expostas, tinha por finalidade resguardar a soberania da sociedade política da concentração de poderes em uma única pessoa ou em único órgão, o que permitiria, em sua visão, um maior equilíbrio no desenvolvimento das relações políticas e sociais.

Não é despiciendo relembrar que a preocupação de usurpação do poder apresentada por John Locke ecoará significativamente em Montesquieu, o que mostra a relevância de sua teorização, de quem recebeu teorização mais completa e elaborada e que acabaria por resultar na clássica teoria da tripartição de poderes que hoje conhecemos. 
Mas a base para a ideia de freios e contrapesos, no entanto, tal como defendido pelo autor francês posteriormente, no sentido de que a divisão é necessária para evitar a concentração e a usurpação nas mãos de uma só pessoa ou grupo, já se encontra suficientemente apresentada por John Locke na obra "Dois tratados do governo civil", constituindo uma das maiores contribuições de sua teoria para o pensamento políticoconstitucional ocidental.

De fato, por tudo que foi debatido no presente artigo, conclui-se que a natural tendência de usurpação do poder por aquele que o detém foi o principal combustível para o aperfeiçoamento da teoria da separação dos poderes, de modo que se, por um lado, John Locke apresentou o germe da discussão ao buscar uma saída para evitar o retorno do absolutismo dos Stuarts, Montesquieu desenvolveu a teorização muito mais completa e elaborada resultando na clássica teoria da tripartição de poderes conhecida nos dias de hoje, de modo que foi o conjunto destes estudos, e muitos outros que foram realizados a partir destes dois, o esteio fundamental para a consolidação desta relevante teoria como princípio fundamental do constitucionalismo moderno.

\section{5- Bibliografia:}

ARANHA, Maria Lúcia de Arruda; MARTINS, Maria Helena Pires. Filosofando: introdução à filosofia. 4. Ed. Rev. São Paulo: Moderna, 2009.

BOBBIO, Norberto. A teoria das formas de governo. Brasília: Editora Universidade de Brasília, 1997.

. Locke e o direito natural. 2.ed. Brasília: Ed. UnB, 1997.

CHEVALLIER, Jean-Jacques. As grandes obras políticas de Maquiavel a nossos dias. Rio de Janeiro: Agir, 1999.

FARIAS NETO, Pedro Sabino de, Ciência política: enfoque integral avançado. São Paulo: Atlas, 2011.

FERRAJOLI, Luigi, A soberania no mundo moderno: nascimento e crise do Estado Naciona, São Paulo: Martins Fontes, 200.

LOCKE, Jonh. Dois tratados do governo Civil. Lisboa: Almedina, 2012. 
MONTESQUIEU, Charles de Secondat, Baron de. O espírito das leis. $3^{\mathrm{a}}$ ed. São Paulo: Martins Fontes, 2005. 